\title{
Transformasi Habitus pada Komunitas Penerima Zakat
}

Oleh

\author{
Dewi Cahyani Puspitasari ${ }^{1}$
}

\begin{abstract}
Abstrak
Pengelolaan zakat yang dilakukan oleh organisasi pengelola zakat (OPZ) mengalami transformasi signifikan sejak pengelolaan zakat tahun 1990-an. Kondisi ini berupa pola distribusi zakat beralih dari ranah amal sosial keagamaan menuju ranah pemberdayaan pengembangan ekonomi. Penelitian ini bermaksud melihat dan memetakan kecenderungan 2 (dua) OPZ dalam mengimplementasikan program pendampingan zakat produktif. Setelah memetakan posisi kedua OPZ tersebut dapat diperoleh deskripsi pola pendampingan yang mengacu pada interpretasi lembaga mengenai zakat produktif. Hasil penelitian menunjukkan bahwa mekanisme transformasi habitus diperoleh dari kegiatan pendampingan yang dilakukan OPZ pada komunitas penerima zakat (dhuafa). Dari pola pendampingan inilah yang kemudian dhuafa melakukan reproduksi pengetahuan dan reproduksi habitus untuk memunculkan praktik sosial berupa 'habitus baru'. Bentuk habitus baru ini ada pada 2 (dua) aspek yaitu habitus zakat dan habitus produktif. Implikasi transformasi habitus ini masih dominan pada level individu belum pada level kelompok (komunitas). Adanya transformasi habitus tersebut juga berimplikasi pada kondisi kemandirian komunitas.
\end{abstract}

Kata kunci : Organisasi Pengelola Zakat (OPZ), transformasi habitus, pendampingan komunitas .

\begin{abstract}
Zakat management conducted by the management organization of zakat (OPZ) experienced a significant transformation since management of zakat in the 1990s. This condition is in the form of zakat distribution pattern shifted from realm of socio-religious charitable toward economic development empowerment. This study intended to see and map the trend of 2 (two) OPZ in implementing assistance of zakat productive program. After mapping position of both OPZ, it can be obtained OPZ assistance pattern description which refers to the interpretation of zakat productive institution. The results showed that mechanism of habitus transformation derived from OPZ assistance activities carried out in the community receiving zakat (dhuafa). From the pattern of assistance, knowledge reproduction and habitus reproduction of dhuafa became social practices that 'new habitus'. This new form of habitus is in 2 (two) aspects of zakat habitus and productive habitus. Implications of this transformation is still dominant habitus at an individual level not at the group level (community). Transformations of habitus are also implications for the conditions of community self-reliance.
\end{abstract}

Keywords : Zakat Management Organisation (OPZ), habitus transformation, community assistance.

\section{A. Pendahuluan}

Keberadaan organisasi lembaga pengelola zakat di Indonesia telah mengalami sejarah yang panjang mendapat perhatian sejak pemerintahan Hindia Belanda. Kondisi ini seperti yang dijelaskan Amiruddin (2005:127) bahwa perkembangan

\footnotetext{
${ }_{1}^{1}$ Dewi Cahyani Puspitasari, menekuni studi tentang koperasi, filantropi, pemberdayaan ekonomi. Saat ini adalah staf pengajar di Jurusan Sosiologi UGM.
} 
Jurnal Pemikiran Sosiologi Volume 2 No. 1, 2013

Transformasi Habitus pada Komunitas Penerima Zakat

Dewi Cahyani Puspitasari

intervensi pemerintah dalam memberikan pendidikan manajemen zakat terus berlanjut sampai pada munculnya beberapa kebijakan berupa peraturan perundangan diantaranya UndangUndang nomor 38 tahun 1999 tentang pengelolaan zakat, keputusan Menteri Agama RI Nomor 373/2003 tentang pelaksanaan UU Nomor 38 tahun 1999 tentang pengelolaan zakat sebagai upaya menyadarkan masyarakat muslim untuk menunaikan zakat. Meski demikian peran negara dalam distribusi zakat melalui Badan Amil Zakat Nasional (BAZNAZ) bukan tanpa kendala yang pada akhirnya memunculkan Lembaga Amil Zakat (LAZ) atau Organisasi Pengelola Zakat (OPZ) yang dikelola oleh pihak swasta (masyarakat).

Pengelolaan dana zakat (ZIS) oleh Organisasi Pengelola Zakat (OPZ) baik skala nasional maupun daerah (lokal) bukan berarti tanpa kritik termasuk di kalangan pegiat zakat atau OPZ yang dipandang zakat justru berpotensi 'melestarikan kemiskinan'. Hal ini seperti pendapat dari Eri Sudewo (2008:102) yaitu ketika masih ada pandangan dari muzakki (pemberi zakat) dan OPZ masih melestarikan antrian zakat maka yang terjadi adalah semacam 'pameran kebajikan' yang ini dapat dimungkinkan antrian zakat ini cenderung bersifat konsumtif dan 'pelestarian kemiskinan'. Pendapat ini tentu tidak lepas dari adanya fakta bahwa OPZ menjadi bagian dari salah satu lembaga kemanusiaan dengan beragam aktivitasnya masih memunculkan program atau kegiatan yang bersifat karitatif (santunan) terlebih saat terjadi bencana dan mengubah aspek kehidupan masyarakat (komunitas) yang terkena bencana maupun kaitannya dengan peran sertanya mengatasi kemiskinan masyarakat (komunitas). Hanya kemudian bila orientasi sebagian besar dari
OPZ masih menjadikan dana zakat yang merupakan salah satu dana kemanusiaan sebagai instrumenkaritatif (santunan) untuk konteks kemiskinan tentu hasilnya belum sampai mengentaskan komunitas penerima zakat (dhuafa) dari kondisi miskinnnya. Kondisi ini kemudian memunculkan transformasi signifikan sejak pengelolaan zakat tahun 1990-an yang beralih dari ranah amal sosial keagamaan semata ke ranah pemberdayaan pengembangan ekonomi. Penjelasan ini tercantum dalam IZDR (2009:13-14) bahwa fokus operasional $\mathrm{OPZ}$ di Indonesia mengalami evolusi yaitu setelah gelombang pertama peralihan fokus OPZ dari ranah amal ke ranah pembangunan, kini muncul gelombang kedua dimana OPZ mulai memberi perhatian pada agenda-agenda advokasi dan pembuatan kebijakan publik yang dapat diilustrasikan gambar sebagai berikut : 
Jurnal Pemikiran Sosiologi Volume 2 No. 1, 2013

Transformasi Habitus pada Komunitas Penerima Zakat

Dewi Cahyani Puspitasari

Gambar 1. Evolusi Fokus Operasional OPZ di

Indonesia

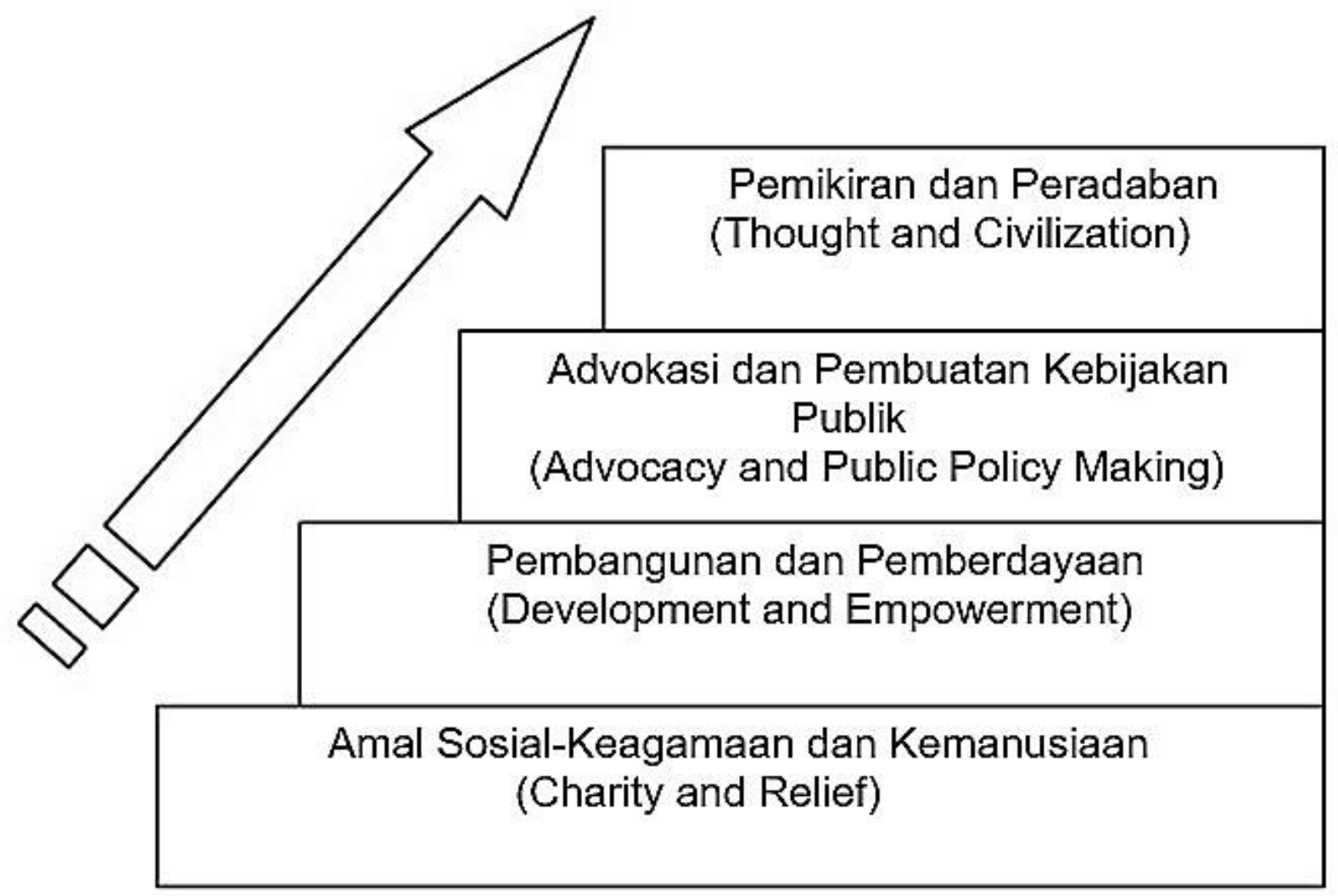

(Sumber : Indonesia Zakat and Development Report (IZDR), 2009)

Dari gambar di atas menunjukkan reorientasi OPZ di Indonesia yang berupaya melakukan perubahan dan pengembangan terhadap pendayagunaan dana kemanusiaan berupa zakat secara bertahap dari amal sosial keagamaan dan kemanusiaan menuju pada pembangunanan dan pemberdayaan untuk lanjut pada advokasi dan pembuatan kebijakan publik serta pemikiran dan peradaban yang berbasis zakat. Dengan demikian melalui peran dari OPZ atau pelaksananya yaitu amil untuk mengelola dan mendayagunakan zakat dapat berperan secara profesional, amanah dan kredibel sehingga zakat dapat memberi nilai tambah positif sesuai dengan yang seharusnya dikehendaki oleh Islam.
Upaya untuk mentransformasi peran zakat agar lebih memberikan manfaat pada masyarakat atau komunitas penerima zakat (dhuafa) dengan kondisi ekonomi dan kesejahteraannya ada pada kategori miskin diantaranya adalah melakukan praktek zakat secara produktif yaitu zakat produktif. Kontribusi dari adanya implementasi pendayagunaan zakat secara produktif ini didukung oleh berbagai studi yang menunjukkan peran instrumen zakat produktif telah memberikan dampak perubahan berupa peningkatan kesejahteraan dan pemberdayaan penerima zakat (dhuafa). Dengan kata lain, zakat dapat digunakan sebagai instrumen dalam pembangunan perekonomian terutama di daerahdaerah yang telah memiliki sistem untuk menerapkan zakat secara luas baik oleh BAZ 
Jurnal Pemikiran Sosiologi Volume 2 No. 1, 2013

Transformasi Habitus pada Komunitas Penerima Zakat

Dewi Cahyani Puspitasari

maupun OPZ. Pengamatan peneliti, sampai sejauh ini kajian zakat belum ada yang secara khusus melihat perubahan kultur atau transformasi habitus dari komunitas penerima zakat (dhuafa). Studi yang ada masih berorientasi pada aspek perubahan dhuafa yang sifatnya materiil yaitu ditinjau dari sisi peningkatan pendapatan, peluang kerja tetapi belum menyentuh pada aspek kedirian (self) dhuafa. Aspek kedirian ini berupa kesediaan dhuafa untuk mengubah nasib agar tidak selamanya menjadi dhuafa tetapi suatu saat dapat menjadi muzakki (donatur zakat). Karena seperti yang kita ketahui khususnya bagi penerima zakat yang ada di wilayah pedesaan, orientasi kehidupannya cenderung masih bersifat fatalis dan masih jarang berorientasi jangka panjang dengan implikasi pada kondisi yang tetap miskin. Tentunya dari sinilah peran dan kontribusi dari pihak OPZ yang pada akhirnya akan menentukan arah ke depan keberhasilan distribusi atau pendayagunaan zakat yang benar-benar secara nyata mampu mengubah kehidupan komunitas dhuafa. Dari adanya realitas empirik tentang praktik sosial berupa distribusi dana zakat produktif inilah yang menjadi ketertarikan peneliti lebih lanjut untuk melakukan kajian mengenai transformasi atau perubahan habitus yaitu aspek kultur ekonomi komunitas dhuafa ditinjau dari aspek pengetahuan (knowledge), perspektif (mindset) dan tindakan atau cara hidup (action). Hal ini menjadi penting untuk dikaji mengingat visi dari adanya distribusi zakat pada dhuafa adalah munculnya perubahan kultur khususnya cara hidup yang pada akhirnya mampu memandirikan komunitas dhuafa.

Dari konteks inilah, peneliti merumuskan masalah penelitian yaitu: Pertama, faktor atau mekanisme apa yang mampu membentuk komunitas penerima zakat untuk melakukan transformasi habitus? Dan kedua, bagaimana hasil (output) dari adanya mekanisme transformasi habitus yang terjadi pada komunitas penerima zakat dan implikasinya pada kemandirian komunitaspenerima zakat? Rumusan tersebut menjadi titik tolak peneliti melakukan penelitian untuk identifikasi dan eksplorasi pengetahuan lokal komunitas dhuafa mengenai zakat produktif yang juga ditinjau dari pihak Organisasi Pengelola Zakat (OPZ) selaku pemberi layanan zakat ZIS (Zakat, Infaq dan Shadaqah) sebagai kesatuan interaksi sosial.

\section{B. Eksistensi Organisasi Pengelola Zakat (OPZ) dan Komunitas Penerima Zakat}

Kedua OPZ dalam penelitian ini menunjukkan kiprah serupa saat pasca gempa di Kabupaten Bantul, Yogyakarta. Keduanya memiliki orientasi program berbeda khususnya bagi penerima program (selanjutnya disebut komunitas penerima zakat) sesuai dengan karakteristik kebutuhan mereka. Dari profil kedua OPZ menunjukkan adanya relevansi antara tujuan program dengan kriteria dan sasaran penerima manfaat program. Hal ini berimplikasi pada adanya kegiatan seleksi dan survei menjadi bagian tak terpisahkan sebelummengimplementasikan program sebagai bentuk tanggung jawab lembaga pada donatur (Muzakki). Selain itu agar program yang diterima benar-benar bermanfaat bagi sasaran (dhuafa) yang membutuhkan. Dengan demikian, harapan lembaga berupa keberhasilan program tidak hanya pada tujuan program semata melainkan kemanfaatan yang diterima oleh penerima program (dhuafa). 
Jurnal Pemikiran Sosiologi Volume 2 No. 1, 2013

Transformasi Habitus pada Komunitas Penerima Zakat

Dewi Cahyani Puspitasari

Profil komunitas penerima zakat (dhuafa) dalam penelitian ini merupakan bentukan sosial khas sesuai dengan konteks sosial kultural yang ada. Dari kondisi geografisnya, komunitas dhuafa terbagi dalam 2 (dua) wilayah pertama, yaitu di Kabupaten Bantul meliputi Kecamatan Banguntapan, Pundong dan Wonokromo. Kedua di Kota Yogyakarta meliputi Kecamatan Ngampilan. Kondisi sosio demografi dapat ditunjukkan dari dari jenis kelamin dan usia, agama dan status perkawinan serta tingkat pendidikan. Dari jenis kelamin dan usia yaitu individu yang tergabung dalam komunitas program Misykat dari DPU-DT yang peneliti wawancara dan ikut sertakan pada FGD (Focus Group Discussion) semuanya adalah perempuan. Kondisi sama dengan kelompok penerima Qardhulhasan (pinjaman tanpa jasa atau bunga) di BMD Seloharjo semuanya adalah kaum ibu yang memiliki usaha meski di kelompok ternak kambing dilakukan oleh laki-laki. Sementara itu untuk kelompok tani dan peternak BMD Amanah mayoritas adalah laki-laki dengan 1 (satu) orang ibu yang menggantikan suaminya yang meninggal dunia. Dari sisi usia rata-rata ada pada usia 40 (empat puluh) tahun dengan kategori usia termuda yaitu usia 34 (tiga puluh empat) tahun untuk lakilaki dan usia 26 (dua puluh enam) tahun untuk perempuan. Kategori usia tertua yaitu 70 (tujuh puluh) tahun untuk laki-laki dan 65 (enam puluh lima) tahun untuk perempuan. Untuk agama, semua informan menganut agama Islam. Meskipun di luar program atau kegiatan yang dilakukan oleh DPU-DT dan BMD dapat diberikan kepada mereka yang non muslim berupa manfaat tidak langsung misalnya seperti yang dijelaskan oleh staf data BMD adanya kegiatan pertanian organik yang menghasilkan berbagai hasil turunan selain padi (beras) dapat melibatkan individu tanpa melihat latar belakang agamanya. Sementara itu untuk status perkawinan dari informan mayoritas menikah, 2 (dua) orang belum menikah dan 1 (satu) orang janda. Bila dilihat dari tingkat pendidikan dari informan yaitu individu yang bergabung di kelompok Misykat DPU-DT, kelompok Qardhulhasan dan petani di BMD rata-rata adalah tamat Sekolah Dasar (SD). Meski demikian terdapat tingkat pendidikan tertinggi adalah Strata 1 (S-1) untuk perempuan dan Sekolah Menengah Atas (SMA) untuk laki-laki.

Konteks kelembagaan dari organisasi pengelola zakat (OPZ) dan kondisi sosio kultural komunitas penerima zakat memberikan gambaran posisi masing-masing sebagai satu kesatuan interaksi. Keberadaan OPZ pada skala regional berimplikasi terhadap cakupan wilayah operasional program lembaga dapat diperuntukkan bagi masyarakat yang berdomisili di Propinsi D.I Yogyakarta. Selain itu dari penjelasan di atas menunjukkan bahwa dinamika kehidupan masyarakat khususnya komunitas penerima zakat dampingan DPU-DT dan BMD cukup beragam sesuai konteks kewilayahannya. Deskripsi tersebut akhirnya sampai pada sebuah konklusi bahwa karakteristik sosial kemasyarakatan dari komunitas penerima zakat menjadi acuan bagi DPU-DT dan BMD untuk melakukan intervensi komunitas melalui pendampingan. Dengan demikian, pemahaman terhadap posisi OPZ dan ragam kondisi komunitas menjadi titik tolak analisis mengenai praktik pendampingan komunitas dan transformasi habitus pada pembahasan selanjutnya. 
Jurnal Pemikiran Sosiologi Volume 2 No. 1, 2013

Transformasi Habitus pada Komunitas Penerima Zakat

Dewi Cahyani Puspitasari

\section{Konstruksi Zakat dan Pendampingan}

\section{Komunitas}

Dana zakat yang diterima oleh OPZ sesuai dengan pengorganisasian dan pengelolaan zakat di Indonesia diatur berdasarkan Undang-Undang Nomor 38 tahun 1999 tentang Pengelolaan Zakat (Bab II Pasal 5). Dalam kaitannya dengan pendayagunaan zakat secara produktif sesuai fokus pencermatan penelitian ini, Yusuf Qardhawi (2005:31-33) menyatakan bahwa zakat produktif ini ada karena terdapat peran zakat dalam mengentaskan kemiskinan. Menurutnya, agar seseorang dapat menunaikan zakatnya untuk mengentaskan kemiskinan mesti diketahui penyebab kemiskinan terhadap individu atau kemiskinan yang terjadi pada satu kelompok masyarakat maupun yang menimpa pada suatu daerah. Hanya saja dalam implementasinya, OPZ memiliki interpretasi berbeda mengenai zakat produktif. Perbedaan pemahaman juga terjadi di komunitas mengenai zakat yang berimplikasi pada ragam pemanfaatan dana zakat yang diterima dhuafa.

Penjelasan mengenai interpretasi zakat produktif baik dari DPU-DT maupun BMD di atas menunjukkan sisi persamaan dan perbedaan pada tataran pemahaman dan implementasinya. Hal ini menunjukkan adanya variasi terhadap interpretasi zakat produktif khususnya dalam implementasinya. Kondisi ini dapat ditunjukkan tabel berikut: 
Jurnal Pemikiran Sosiologi Volume 2 No. 1, 2013

Transformasi Habitus pada Komunitas Penerima Zakat

Dewi Cahyani Puspitasari

Tabel 1. Interpretasi Zakat Produktif DPU-DT dan BMD

\begin{tabular}{|c|c|c|}
\hline \multirow[t]{2}{*}{ Interpretasi } & \multicolumn{2}{|c|}{ OPZ } \\
\hline & DPU-DT & BMD \\
\hline Persamaan & \multicolumn{2}{|c|}{$\begin{array}{l}\text { 1. Dasar hukum (fiqh Islam tidak mengacu pada satu pendapat (fatwa) } \\
\text { melainkan lebih pada unsur kebolehan (mubah) pengelolaan zakat untuk usaha } \\
\text { produktif } \\
\text { 2. Tujuan utama dari distribusi zakat produktif adalah perubahan kondisi } \\
\text { dhuafa (penerima zakat) yaitu dari kondisi miskin menjadi meningkat kualitas } \\
\text { hidupnya atau pada tahap kemandirian. } \\
\text { 3. Tujuan program atau kegiatan mempertimbangkan manfaat masyarakat di } \\
\text { lingkungan sekitar komunitas dhuafa (penerima zakat) atau disebut dengan } \\
\text { multiplier effect }\end{array}$} \\
\hline \multirow[t]{2}{*}{ Perbedaan } & $\begin{array}{l}\text { 1. Metode pendekatan pada } \\
\text { komunitas dhuafa (penerima zakat): } \\
\text { bersifat langsung melalui pertemuan } \\
\text { rutin kelompok dengan pendamping }\end{array}$ & $\begin{array}{l}\text { 1. Metode pendekatan pada komunitas } \\
\text { dhuafa (penerima zakat): bersifat tidak } \\
\text { langsung. Hal ini dikarenakan adanya } \\
\text { pembagian tugas antara BMD Centre } \\
\text { dan BMD Lokal. Komunikasi dengan } \\
\text { dhuafa secara intens dilakukan oleh } \\
\text { pengelola BMD Lokal. }\end{array}$ \\
\hline & $\begin{array}{l}\text { 2. Implementasi program atau } \\
\text { kegiatan distribusi zakat produktif: } \\
\text { Misykat berupa dana bergulir dan } \\
\text { pendampingan }\end{array}$ & $\begin{array}{l}\text { 2. Implementasi program atau kegiatan } \\
\text { distribusi zakat produktif: Pertanian } \\
\text { padi organik dan Qardhulhasan } \\
\text { (pinjaman tanpa bunga) }\end{array}$ \\
\hline
\end{tabular}

(Sumber: data primer peneliti, olah data penelitian).

Berdasarkan tabel di atas dijelaskan bahwa pada sisi persamaan terdapat 3 (tiga) hal yaitu pertama, dasar hukum Islam lebih pada zakat produktif lebih pada unsur mubah (kebolehan); kedua, tujuan utama dari distribusi zakat produktif adalah untuk kemandirian dhuafa (penerima zakat) berupa peningkatan kualitas hidup dan ketiga yaitu tujuan program atau kegiatan berdampak pada lingkungan (multiplier 
effect). Sedangkan pada sisi perbedaan ada pada 2 (dua) aspek yaitu metode pendekatan pada komunitas dhuafa (penerima zakat) dan implementasi program atau kegiatan distribusi zakat produktif. Adanya perbedaan ini sesuai dengan penjelasan sebelumnya bahwa DPU-DT dan BMD selain memiliki interpretasi mengenai zakat produktif berbeda yang berimplikasi pada perbedaan implementasi juga pada adopsi terhadap konsep pemberdayaan komunitas. Selanjutnya, pemahaman zakat di komunitas penerima zakat cukup beragam sesuai konteks komunitas penerima zakat dalam penelitian ini ada pada kondisi pasca bencana gempa. Pengetahuan zakat komunitas dhuafa dapat ditunjukkan tabel berikut :
Tabel 2. Pengetahuan Komunitas Penerima Zakat Terhadap Zakat Produktif

\begin{tabular}{|l|l|}
\hline Komunitas & \multicolumn{1}{|c|}{ Pengetahuan Zakat Produktif } \\
\hline DPU-DT & $\begin{array}{l}\text { 1. Zakat adalah bantuan (santunan) } \\
\text { 3. Zakat adalah kewajiban dalam } \\
\text { Islam (ibadah) } \\
\text { BMD }\end{array}$ \\
$\begin{array}{l}\text { 4. Zakat adalah keuntungan dari } \\
\text { tidak mampu } \\
\text { 5. Zakat adalah mengeluarkan } \\
\text { sebagian harta yang dimiliki } \\
\text { 6. Zakat adalah kewajiban orang } \\
\text { kaya (mampu) } \\
\text { 7. Zakat adalah pemberian harta } \\
\text { atau benda secara ikhlas dan } \\
\text { sukarela }\end{array}$ \\
\hline
\end{tabular}

(Sumber: Data primer peneliti, olah data penelitian)

Berdasarkan tabel tersebut dapat ditunjukkan bahwa pengetahuan komunitas penerima zakat mengenai zakat produktif masih beragam. Hal ini berkaitan dengan ketersediaan pengetahuan (stock of knowledge) dari komunitas penerima zakat dengan kultur pemanfaatan dana zakat. Meski hal ini juga perlu mempertimbangkan karakteristik dari penerima zakat yang beragam latar belakang pendidikan, usia dan tingkat kebutuhan sosial ekonominya. Kondisi tersebut berimplikasi pada ragam pemanfaatan dana zakat oleh komunitas 
Jurnal Pemikiran Sosiologi Volume 2 No. 1, 2013

Transformasi Habitus pada Komunitas Penerima Zakat

Dewi Cahyani Puspitasari

penerima zakat yang ditunjukkan tabel sebagai berikut :

Tabel 3. Ragam Pemanfaatan Dana Zakat Komunitas

\begin{tabular}{|c|c|}
\hline $\begin{array}{c}\text { Kategori } \\
\text { Zakat }\end{array}$ & Bentuk Pemanfaatan \\
\hline Zakat Fitrah & $\begin{array}{l}\text { Memenuhi kebutuhan pangan } \\
\text { (beras keluarga) }\end{array}$ \\
\hline $\begin{array}{l}\text { Zakat Maal } \\
\text { (berupa } \\
\text { uang) }\end{array}$ & $\begin{array}{l}\text { 1. Merintis usaha baru } \\
\text { 2. Menambah modal usaha } \\
\text { 3. Membenahi rumah atau } \\
\text { tempat tinggal } \\
\text { 4. Menambah uang saku anak } \\
\text { sekolah } \\
\text { 5. Membiayai pendidikan } \\
\text { atau sekolah anak } \\
\text { 6. Biaya pengobatan (khusus } \\
\text { saat penerima zakat dalam } \\
\text { kondisi sakit parah) }\end{array}$ \\
\hline
\end{tabular}

(Sumber: data primer peneliti, olah data primer penelitian).

Bila dilihat pada tabel menunjukkan porsi atau alokasi pemanfaatan zakat masih dominan untuk pemenuhan konsumtif meliputi pangan, rumah tinggal, pendidikan dan pengobatan (kesehatan). Sementara itu untuk pemanfaatan produktif atau dikenal dengan zakat produktif ada pada aspek merintis usaha baru serta menambah modal usaha dari komunitas penerima zakat.

Penjabaran mengenai interpretasi potensi dan sumberdaya yang dimiliki zakat produktif baik pada OPZ (organisasi penerima zakat) maupun komunitas penerima zakat pada pembahasan sebelumnya memberikan konsekuensi khususnya OPZ untuk melakukan pendampingan komunitas penerima zakat. Penerjemahan terhadap tujuan dan konsep zakat yang didekatkan dengan paradigma pengembangan masyarakat (community development) melalui aksi pendampingan seperti yang dikaji oleh peneliti melalui 2 (dua) OPZ ini memiliki prinsip seperti yang disampaikan oleh disampaikan oleh Halim dalam Nana (2010:38) yaitu (1) berorientasi pada kesejahteraan lahir dan batin untuk membenahi kehidupan sosial bersama masyarakat agar penindasan dan ketidakadilan tidak lagi hidup di tengah-tengah mereka; (2) rekayasa sosial yang merupakan proses perencanaan perubahan sosial untuk menuju tatanan kehidupan yang lebh baik; (3) program yang dijalankan harus didasarkan atas dan untuk memenuhi kebutuhan masyarakat; (4) menekankan pada keterlibatan masyarakat secara akti dalam melaksanakan program mulai dari perencanaan sampai evaluasi dan pengembangan; memadukan seluruh potensi dan sumberdaya oleh masyarakat dan (6) berkelanjutan.

Mencermati lebih lanjut adanya aktivitas pendampingan oleh OPZ ini relevan dengan konsep transformasi. Pendapat Delaney dalam Gauthamadas (2005:5\&6) menyatakan bahwa proses transformasi merupakan aksi meningkatkan kapasitas manusia, budaya dan modal sosial termasuk transformasi peran gender, transformasi 
Jurnal Pemikiran Sosiologi Volume 2 No. 1, 2013

Transformasi Habitus pada Komunitas Penerima Zakat

Dewi Cahyani Puspitasari

dari kelompok yang memiliki kerentanan,

pemberdayaan sosial ekonoomi, manajemen

lingkungan dan peningkatan kapasitas lokal.

Berdasarkan penjelasan Gauthamadas tersebut

Gambar 2. Pendampingan OPZ Sebagai Proses Transformasi

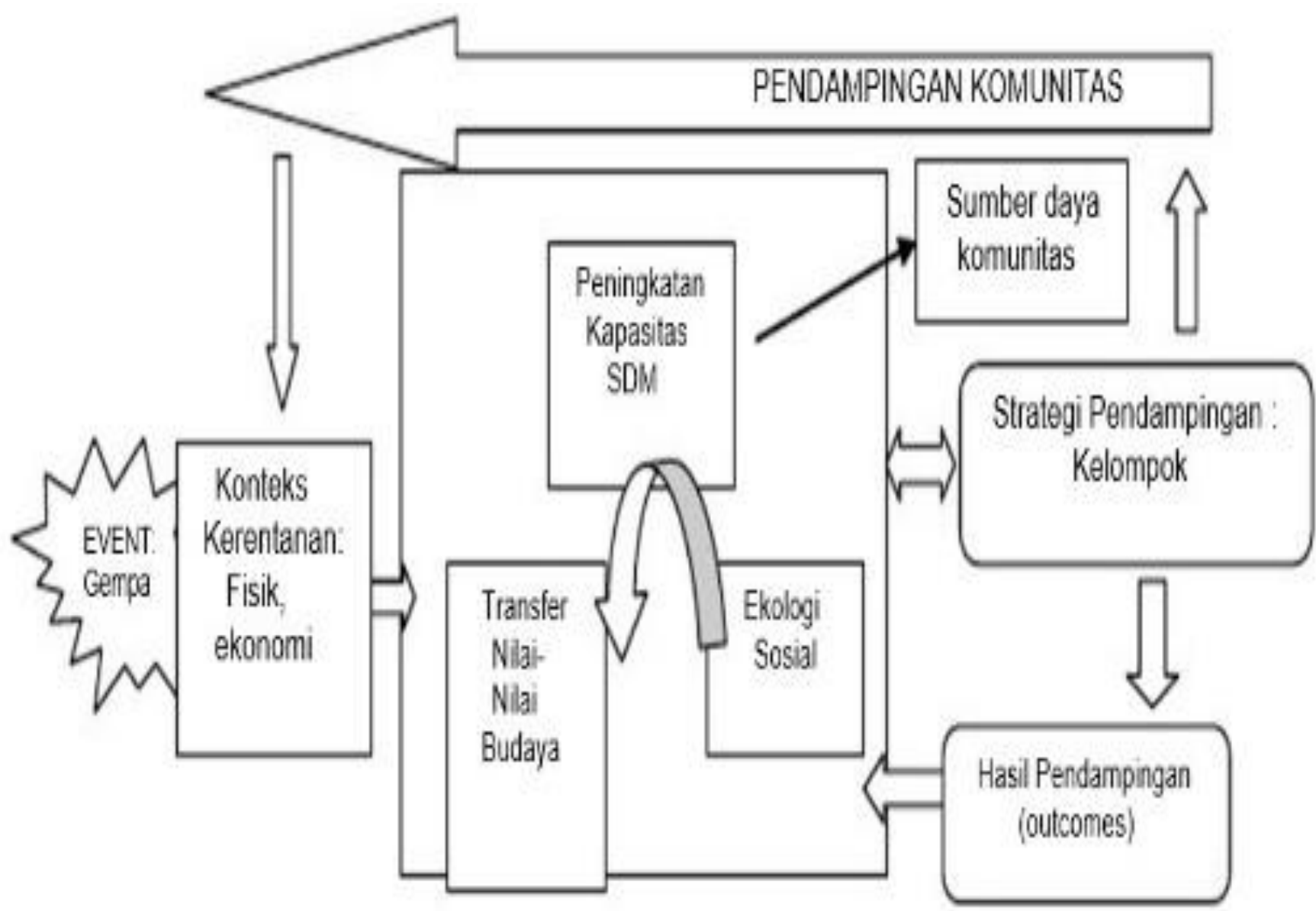

(Sumber: diadaptasi peneliti dari kerangka transformasi sosial (Mak dalam Gauthamadas, 2005) 
Jurnal Pemikiran Sosiologi Volume 2 No. 1, 2013

Transformasi Habitus pada Komunitas Penerima Zakat

Dewi Cahyani Puspitasari

Dari gambar di atas dapat dijelaskan bahwa konteks lokasi penelitian yang merupakan kelompok komunitas (sasaran) program implementasi distribusi zakat produktif oleh OPZ (DPU-DT dan BMD) adalah korban gempa bumi. Hal ini berimplikasi pada adanya kerentanan fisik berupa ketiadaan atau rusaknya tempat tinggal dan tempat usaha serta kerentanan ekonomi berupa ketiadaan modal untuk merintis usaha kembali. Kehadiran OPZ melalui aktivitas pendampingan merupakan sinergitas proses yaitu untuk mengoptimalkan sumberdaya komunitas melalui peningkatan kapasitas untuk mentransfer nilai-nilai budaya dan menunjang kemanfaatan lingkungan sosial (ekologi sosial). Strategi pendampingan melalui kelompok memberi kemudahan untuk mengorganisasikan individu penerima zakat sehingga target atau tujuan dari pendampingan dapat memberikan hasil optimal berupa 'transformasi produktif' pada komunitas.

\section{Dari Pendampingan Menuju Transformasi Habitus}

Program atau kegiatan yang diintervensikan oleh OPZ pada komunitas penerima zakat diharapkan dapat memunculkan 'transformasi produktif' melalui instrumen ekonomi partisipatif berupa keuangan mikro berbasis masyarakat (Misykat) di DPU-DT maupun Qardhulhasan (pinjaman tanpa bunga), peternakan kambing dan pertanian organik di BMD. Selanjutnya dari adanya praktik pendampingan, peneliti mengkoneksikannya dengan konsep habitus. Secara konsep, menurut Richard Jenkins (dalam Fashri,2007:91), habitus bisa didekati melalui 3 (tiga) pandangan berbeda yaitu (a) kondisi objektif menghasilkan habitus, (b) habitus disesuaikan dengan kondisi objektif dan (c) terdapat hubungan resiprokal atau dialektis di antara mereka. Habitus juga dapat dipilah menjadi dua aspek yaitu habitus yang dimiliki individu (habitus individu) yang secara khas didapatkan oleh individu melalui pengalaman dan sosialisasi dan 'habitus kolektif' sebagai fenomena kolektif yang menunjuk pada suatu kelas. Berdasarkan konsep tersebut, peneliti melakukan identifikasi habitus komunitas yang mengarah pada 'habitus individu' dan 'habitus kolektif'. Dari ragam habitus tersebut,peneliti memunculkan kategorisasi 'habitus zakat' dan 'habitus produktif' yang mengacu hasil penelitian. Berikut penjelasannya :

\section{Habitus Komunitas DPU-DT}

\section{a. Habitus Individu}

Habitus dalam pengertian Bourdieu (dalam Fashri,2007:87) bahwa habitus sebagai perlengkapan dan postur sebagai posisi tubuh/fisik juga kualitas sebagai sifat-sifat menetap dalam diri yang lama kelamaan membentuk sifat yang relatif menetap. Berdasarkan penjelasan ini berikut identifikasi habitus individu dari komunitas DPUDT: 
Jurnal Pemikiran Sosiologi Volume 2 No. 1, 2013

Transformasi Habitus pada Komunitas Penerima Zakat

Dewi Cahyani Puspitasari

Tabel 4. Habitus Individu Komunitas DPU-DT

\begin{tabular}{|c|c|c|}
\hline \multirow[t]{2}{*}{ Kategori Habitus } & \multicolumn{2}{|c|}{ Kondisi Habitus Individu } \\
\hline & Sebelum Pendampingan & Sesudah Pendampingan \\
\hline \multirow{3}{*}{ Habitus Zakat } & $\begin{array}{l}\text { Individu memahami zakat sebagai } \\
\text { bantuan yang sifatnya konsumtif } \\
\text { (langsung habis). }\end{array}$ & $\begin{array}{l}\text { Individu mulai memahami dana zakat } \\
\text { untuk usaha produktif. }\end{array}$ \\
\hline & $\begin{array}{l}\text { Individu memanfaatkan zakat untuk } \\
\text { kebutuhan sehari-hari berupa } \\
\text { makanan,biaya pendidikan dan } \\
\text { kesehatan. }\end{array}$ & $\begin{array}{l}\text { Individu memanfaatkan dana zakat untuk } \\
\text { usaha produktif. }\end{array}$ \\
\hline & $\begin{array}{l}\text { Individu masih lebih banyak } \\
\text { menerima zakat daripada membayar } \\
\text { zakat. }\end{array}$ & $\begin{array}{l}\text { Individu mulai membiasakan berinfaq atau } \\
\text { berzakat mandiri. }\end{array}$ \\
\hline \multirow{3}{*}{ Habitus Produktif } & $\begin{array}{l}\text { Individu belum mengenal dan } \\
\text { mengaplikasikan manajemen usaha } \\
\text { sehingga belum ada kemajuan usaha. }\end{array}$ & $\begin{array}{lcc}\text { Individu mulai mengenal } & \text { dan } \\
\text { mengaplikasikan manajemen usaha. } & \end{array}$ \\
\hline & $\begin{array}{l}\text { Individu belum mengenal dan } \\
\text { mengaplikasikan manajemen } \\
\text { keuangan sehingga jarang atau tidak } \\
\text { ada dana yang ditabung sebagai } \\
\text { cadangan atau investasi. }\end{array}$ & $\begin{array}{l}\text { Individu mulai mengenal dan } \\
\text { mengaplikasikan manajemen keuangan } \\
\text { dan membiasakan menabung. }\end{array}$ \\
\hline & $\begin{array}{l}\text { Individu belum mengenal dan } \\
\text { mengaplikasikan } \\
\text { pemasaran sehingga belum ada } \\
\text { perluasan pasar. }\end{array}$ & $\begin{array}{l}\text { Individu mulai mengenal dan } \\
\text { mengaplikasikan manajemen pemasaran } \\
\text { sehingga mulai ada perluasan pasar. }\end{array}$ \\
\hline
\end{tabular}

(Sumber: data primer peneliti, olah data penelitian) 
Berdasarkan tabel di atas menunjukkan bahwa terdapat perbedaan habitus individu, yaitu sebelum dan setelah adanya pendampingan. Pada habitus zakat, sebelum pendampingan individu masih memahami zakat sebagai bantuan yang sifatnya konsumtif tapi kemudian setelah pendampingan mulai ada pemahaman dana zakat untuk usaha produktif.

Selanjutnya, sebelum pendampingan individu memanfaatkan zakat untuk pemenuhan kebutuhan sehari-hari, pendidikan dan kesehatan tapi setelah pendampingan mulai ada alokasi zakat untuk usaha produktif. Selain itu, sebelum pendampingan masih menerima zakat tapi setelah pendampingan mulai membiasakan berinfaq atau zakat mandiri. Adanya habitus individu ini dimana individu tergabung dalam kelompok Misykat memberi implikasi pada adanya habitus kolektif baik pada habitus zakat maupun habitus produktif.

\section{$\underline{\text { b. Habitus Kolektif }}$}

Pencermatan habitus kolektif ini merujuk pendapat Jenkins pada penjelasan sebelumnya bahwa habitus kolektif menunjuk pada suatu kelas atau kelompok. Dalam hal ini peneliti mengidentifikasi habitus kolektif komunitas DPU-DT sebagai berikut :
Tabel 5. Habitus Kolektif Komunitas DPU-DT

\begin{tabular}{|l|l|}
\hline $\begin{array}{l}\text { Kategori } \\
\text { Habitus }\end{array}$ & Kondisi Habitus Kolektif \\
\hline Habitus Zakat & $\begin{array}{l}\text { Mekanisme berzakat sifatnya } \\
\text { sukarela dari individu dengan } \\
\text { konsep Zakat Mandiri dalam } \\
\text { kelompok }\end{array}$ \\
\hline $\begin{array}{l}\text { Habitus } \\
\text { Produktif }\end{array}$ & $\begin{array}{l}\text { Mekanisme usaha bersama } \\
\text { belum dapat terwujud karena } \\
\text { orientasi usaha masih bersifat } \\
\text { individual }\end{array}$ \\
\hline
\end{tabular}

(Sumber: data primer peneliti, olah data penelitian) Berdasarkan tabel tersebut menunjukkan bahwa habitus kolektif berupa habitus zakat sifatnya sukarela dari individu melalui mekanisme zakat mandiri dimana masing-masing anggota menyetorkan dana infaq atau zakat dalam kelompok. Sementara untuk habitus produktif berupa usaha bersama belum dapat terwujud karena orientasi usaha masih bersifat individual.

\section{Habitus Komunitas BMD}

Pencermatan habitus komunitas BMD ini mengacu pada kategorisasi pada pembahasan sebelumnya sesuai dengan hasil penelitian sebagai berikut:

a. Habitus Individu: Identifikasi habitus individu mengacu pada penjelasan sebelumnya yang diilustrasikan tabel di bawah sebagaimana berikut ini: 
Jurnal Pemikiran Sosiologi Volume 2 No. 1, 2013

Transformasi Habitus pada Komunitas Penerima Zakat

Dewi Cahyani Puspitasari

Tabel 6. Habitus Individu Komunitas BMD

\begin{tabular}{|c|c|c|}
\hline \multirow[t]{2}{*}{ Kategori Habitus } & \multicolumn{2}{|c|}{ Kondisi Habitus Individu } \\
\hline & Sebelum Pendampingan & Sesudah Pendampingan \\
\hline \multirow{3}{*}{ Habitus Zakat } & $\begin{array}{l}\text { Individu masih berorientasi sebagai } \\
\text { penerima zakat belum penyantun } \\
\text { zakat. }\end{array}$ & $\begin{array}{l}\text { Individu mulai ada kesadaran berinfaq } \\
\text { rutin (buku infaq BMD) dan membayar } \\
\text { zakat (fitrah). }\end{array}$ \\
\hline & $\begin{array}{l}\text { Individu memahami zakat sebagai } \\
\text { bantuan yang sifatnya konsumtif } \\
\text { (langsung habis). }\end{array}$ & $\begin{array}{l}\text { Individu mulai memahami adanya dana } \\
\text { zakat untuk usaha produktif. }\end{array}$ \\
\hline & $\begin{array}{l}\text { Individu memanfaatkan zakat untuk } \\
\text { kebutuhan sehari-hari berupa } \\
\text { makanan, biaya pendidikan dan } \\
\text { kesehatan. }\end{array}$ & $\begin{array}{l}\text { Individu mulai memanfaatkan zakat untuk } \\
\text { usaha produktif. }\end{array}$ \\
\hline \multirow{3}{*}{ Habitus Produktif } & $\begin{array}{l}\text { Individu belum mengenal dan } \\
\text { mengaplikasikan manajemen usaha. }\end{array}$ & $\begin{array}{l}\text { Individu mulai mengenal dan aplikasikan } \\
\text { manajemen usaha. }\end{array}$ \\
\hline & $\begin{array}{l}\text { Individu belum mengenal dan } \\
\text { mengaplikasikan } \\
\text { keuangan sehingga jarang atau tidak } \\
\text { ada dana yang ditabung. }\end{array}$ & Individu mulai membiasakan menabung. \\
\hline & $\begin{array}{l}\text { Individu belum mengenal dan } \\
\text { mengaplikasikan } \\
\text { pemasaran sehingga belum ada } \\
\text { perluasan pasar. }\end{array}$ & $\begin{array}{l}\text { Individu mulai mengembangkan jaringan } \\
\text { untuk pemasaran usaha. }\end{array}$ \\
\hline
\end{tabular}

(Sumber: data primer peneliti, olah data penelitian) 
Jurnal Pemikiran Sosiologi Volume 2 No. 1, 2013

Transformasi Habitus pada Komunitas Penerima Zakat

Dewi Cahyani Puspitasari

Berdasarkan tabel tersebut, kondisi habitus individu pada habitus zakat, sebelum pendampingan pada pemahaman zakat sebagai bantuan dengan pemanfaatan untuk kebutuhan konsumtif dan belum adanya kebiasaan berzakat. Hal ini menjadi berbeda setelah pendampingan, individu mulai ada kesadaran berinfaq secara rutin, memanfaatkan dana zakat untuk usaha produktif.

b. Habitus Kolektif: Identifikasi habitus kolektif mengacu pada penjelasan sebelumnya yang ditunjukkan tabel berikut :

Tabel 7. Habitus Kolektif Komunitas BMD

\begin{tabular}{|l|l|}
\hline Kategori & Kondisi Habitus Kolektif \\
\hline Habitus Zakat & $\begin{array}{l}\text { Mekanisme berzakat sifatnya } \\
\text { sukarela dari individu } \\
\text { langsung pada pengelola } \\
\text { BMD. }\end{array}$ \\
\hline $\begin{array}{l}\text { Habitus } \\
\text { Produktif }\end{array}$ & $\begin{array}{l}\text { Mekanisme kelompok tani } \\
\text { untuk pengelolaan pertanian } \\
\text { padi dan peternakan } \\
\text { kambing. }\end{array}$ \\
\hline
\end{tabular}

(Sumber: data primer peneliti, olah data penelitian) Berdasarkan ilustrasi tabel di atas menunjukkan kondisi habitus kolektif pada habitus zakat masih bersifat sukarela yang disetorkan melalui pengelola BMD. Kondisi ini berbeda dengan komunitas DPUDT yang mulai membiasakan berinfaq atau berzakat dalam kelompok. Hal ini dikarenakan manajemen pengelolaan zakat dilakukan langsung oleh pengelola BMD selaku pihak yang bertanggung jawab atas distribusi zakat dari donatur BMD. Sementara untuk habitus produktif dilakukan melalui mekanisme kelompok tani untuk pengelolaan pertanian padi dan peternakan kambing. Dengan demikian, kelompokmemberi konsekuensi munculnya habitus produktif secara kolektif untuk pengembangan usaha.

Deskripsi tersebut bila dikoneksikan dengan konsep habitus menjadi relevan yaitu praktik pendampingan telah berhasil mengedukasi dan mentransformasi pengetahuan untuk kemudian komunitas atau dalam hal ini secara khusus individu melakukan respons dari adanya proses tersebut. Bentuk respons tersebut muncul dalam 'perilaku reproduktif dari pengetahuan baru yang diperoleh individu penerima zakat dalam komunitasnya melalui praktik pendampingan. Perilaku reproduktif ini dilakukan karena adanya proses penyadaran dalam praktik pendampingan untuk menjawab masalah (kerentanan) yang dihadapi individu penerima zakat pasca bencana. Kondisi ini dapat diilustrasikan sebagai berikut : 
Gambar. 3 Perilaku Reproduktif Komunitas

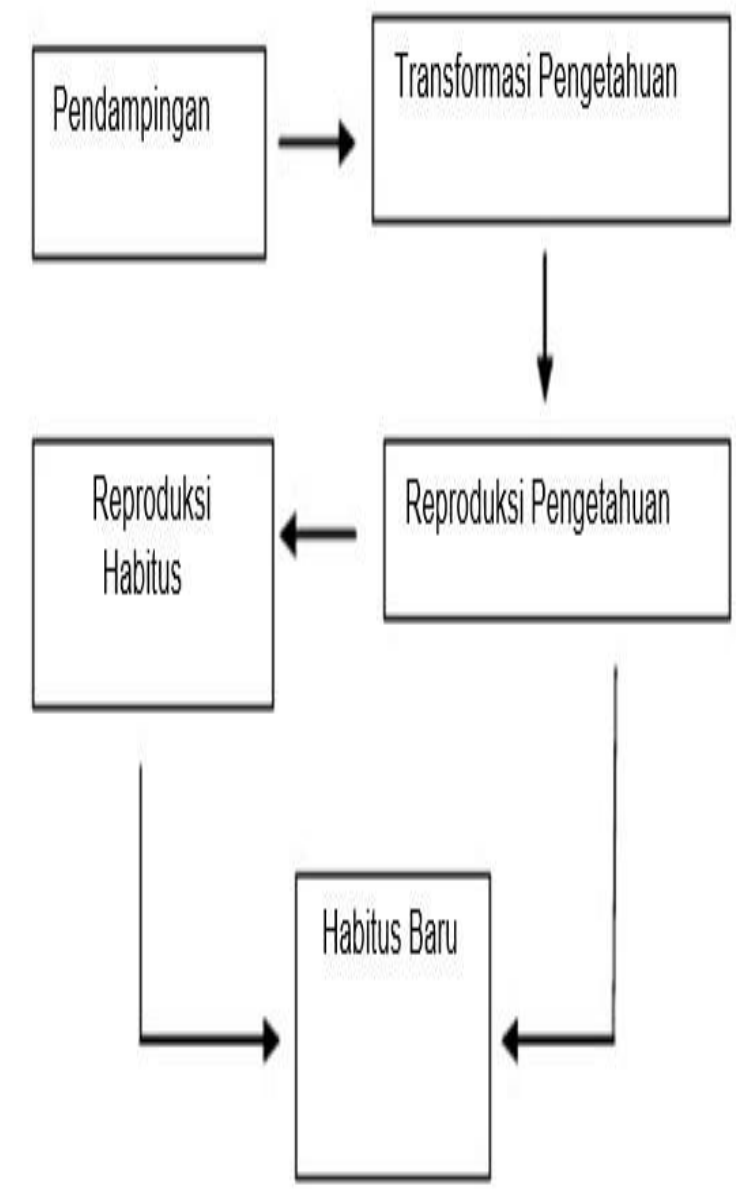

Sumber: Pemikiran kajian dan elaborasi peneliti.

Berdasarkan gambar di atas dapat ditunjukkan bahwa adanya pendampingan memberi implikasi pada transformasi pengetahuan yang kemudian diadopsi oleh individu pada komunitas penerima zakat atau disebut reproduksi pengetahuan. Bentuk reproduksi pengetahuan yang berupa pengetahuan agama dan ekonomi menjadikan proses reproduksi habitus yang merupakan pembaruan atas 'habitus lama' dari individu penerima zakat. Dari kedua proses inilah kemudian memberikan kapasitas pada individu penerima zakat untuk melakukan pola tindakan 'habitus baru' sebagai hasil dari adanya pendampingan oleh OPZ.

\section{E. Penutup}

Pembahasan hasil penelitian ini menunjukkan adanya transformasi habitus berupa perubahan habitus individu (dhuafa) dan habitus kolektif (komunitas). Mekanisme transformasi habitus ini diperoleh dari adanya praktik pendampingan yang berimplikasi pada transformasi pengetahuan individu penerima zakat (dhuafa). Selain itu, adanya kapasitas individu (dhuafa) untuk mereproduksi pengetahuan yang diperoleh dari kegiatan pendampingan berimplikasi pada praktik sosial kehidupan sehari-hari mereka sebagai suatu 'habitus baru'. Bentuk 'habitus baru' tersebut ada pada 2 (dua) aspek yaitu; pertama, habitus untuk menunaikan zakat yang menjadi indikasi transformasi dhuafa dari penerima zakat sebagai pemberi zakat meskipun masih pada zakat fitrah. Kedua, habitus produktif berupa peningkatan kapasitas dari dhuafa untuk mengelola dana zakat yang diterima untuk kegiatan produktif sesuai keterampilan dan jenis usaha yang ada.

Proses transformasi habitus pada komunitas penerima zakat bukan tanpa kendala karena adanya aspek pengetahuan serta pemahaman komunitas dan lingkungan sosial mengenai zakat produktif yang dianggap sebagai hal baru dalam distribusi zakat dari OPZ. Perbedaan inilah yang menjadi salah satu pembeda proses transformasi habitus antara individu satu dengan lainnya dalam satu komunitas penerima zakat. Selain itu, kendala dalam mengelola dana zakat yang diterima komunitas untuk 
Jurnal Pemikiran Sosiologi Volume 2 No. 1, 2013

Transformasi Habitus pada Komunitas Penerima Zakat

Dewi Cahyani Puspitasari

kepentingan ekonomi mereka yaitu masih adanya perlakuan zakat sebagai pengeluaran tanpa pengembalian yang mempunyai dampak positif bagi transformasi ekonomi mereka. Kondisi ini kemudian direspon oleh OPZ yang tidak hanya mendistribusikan dana zakat melalui suatu program atau kegiatan tetapi juga diikuti dengan pendampingan intensif pada komunitas. Adanya proses pendampingan inilah yang kemudian mengaktifkan interaksi individu dalam satu komunitas penerima zakat secara bersama-sama memobilisasi kapasitas dan modal yang ada untuk transformasi ekonomi dan habitus mereka.

\section{Daftar Pustaka}

Amiruddin,dkk. 2005. Anatomi Fiqih Zakat-Potret dan Pemahaman Badan Amil Zakat Sumatera Selatan. Yogyakarta: Pustaka Pelajar.

Bourdieu,Pierre (terj). 2010. Arena Produksi Kultural: Sebuah Kajian Sosiologi Budaya. Yogyakarta: Kreasi Wacana.

Bourdieu, Pierre. 1990. The Logic of Practice. Cambridge: Cambridge Studies in Social and Anthropology. Diakses melalui laman http://www.library.nu.diakses tanggal 21 November 2010.

Fashri, Fauzi. 2007. Penyingkapan Kuasa Simbol. Yogyakarta: Juxtapose.

Gauthamadas. 2010. Social transformation of the tsunami affected fishing community: the concept and the need. Artikle diakses dari laman http://www.ADEPT.org. Diakses tanggal 20 November

Harker, Richard dkk. 2009. (Habitus $x$ Modal)+Ranah=Praktik: Pengantar Paling Komprehensif kepada Pemikiran Pierre Bourdieu. Yogyakarta: Jalasutra.

Houston,Stan. 2002. "Reflectingon Habitus,Field and Capital", dalam Journal of Social Work Vol II, No.2. Diakses dari laman http://www.sagepub.com. Diakses tanggal 1 September 2010.

Mills, Carmen. 2008. "Reproduction and Transformation of Inequalities in schooling: the transformative potential of the theoretical constructs of Bourdieu", dalam British Journal of Sociology of Education Vol. 29 No.1, diakses dari laman http://www.informaworld.com. Diakses tanggal 25 April 2011. 
Jurnal Pemikiran Sosiologi Volume 2 No. 1, 2013

Transformasi Habitus pada Komunitas Penerima Zakat

Dewi Cahyani Puspitasari

Mintarti, Nana dan Gito Haryanto. 2010.

"Pemberdayaan Masyarakat Berbasis Zakat

Studi Kasus Perajin Gula Kelapa di

Kabupaten Pacitan", dalam Jurnal Zakat \&

Empowering, Volume 3, edisi: September.

Mustafa, dkk. 2009. "IZDR 2010: Menggagas Arsitektur Zakat Indonesia, Menuju Sinergi Pemerintah dan Masyarakat Sipil", dalam Pengeololaan Zakat Nasional. Jakarta: PEBSUI dan IMZ.

Qardhawi,Yusuf. 2005. Spektrum Zakat Dalam Membangun Ekonomi Kerakyatan. Jakarta:Zikrul Hakim.

Rukminto, Isbandi. 2008. Intervensi Komunitas Pengembangan Masyarakat Sebagai Upaya Pemberdayaan Masyarakat. Jakarta: Raja Grafindo Persada.

Sudewo, Erie. 2008. Politik Ziswaf Kumpulan Esei. Jakarta: UI Press dan CID.

Sutisna, Nana dan Samsul Maarif. 2010. "Baitul Maal Desa, Menemukan Model Pemberdayaan Masyarakat Berbasis Zakat", dalam Jurnal Zakat \& Empowering, Volume 3, edisi: September. 